\title{
Importance of longwave emissions from adjacent terrain on patterns of tropical glacier melt and recession
}

\author{
CAROLINE AUBRY-WAKE, ${ }^{1,2}$ DORIAN ZÉPHIR, ${ }^{3}$ MICHEL BARAER, ${ }^{4}$ \\ JEFFREY M. MCKENZIE, ${ }^{5}$ BRYAN G. MARK ${ }^{6}$ \\ ${ }^{1}$ Department of Earth and Planetary Sciences, McGill University, Montréal, Québec, Canada \\ ${ }^{2}$ Centre for Hydrology, University of Saskatchewan, Saskatoon, Saskatchewan, Canada \\ ${ }^{3}$ Département de génie de la construction, École de Technologie Supérieure, Montréal, Québec, Canada \\ ${ }^{4}$ Département de génie de la construction, École de Technologie Supérieure, Montréal, Québec, Canada \\ ${ }^{5}$ Department of Earth and Planetary Sciences, McGill University, Montréal, Québec, Canada \\ ${ }^{6}$ Department of Geography, The Ohio State University, Columbus, OH, USA \\ Correspondence: Caroline Aubry-Wake <caroline.aubrywake@usask.ca>
}

\begin{abstract}
Tropical glaciers constitute an important source of water for downstream populations. However, our understanding of glacial melt processes is still limited. One observed process that has not yet been quantified for tropical glaciers is the enhanced melt caused by the longwave emission transfer. Here, we use high-resolution surface temperatures obtained from the thermal infrared imagery of the Cuchillacocha Glacier, in the Cordillera Blanca, Peru in June 2014 to calculate a margin longwave flux. This longwave flux, reaching the glacier margin from the adjacent exposed rock, varies between 81 and $120 \mathrm{~W} \mathrm{~m}^{-2}$ daily. This flux is incorporated into a physically-based melt model to assess the net radiation budget at the modeled glacier margin. The simulation results show an increase in the energy available for melt by an average of $106 \mathrm{~W} \mathrm{~m}^{-2}$ during the day when compared with the simulation where the $L W_{\text {margin }}$ flux is not accounted for. This value represents an increase in ablation of $\sim 1.7 \mathrm{~m}$ at the glacier margin for the duration of the dry season. This study suggests that including the quantification of the glacier margin longwave flux in physically-based melt models results in an improved assessment of tropical glacier energy budget and meltwater generation.
\end{abstract}

KEYWORDS: energy balance, melt - surface, mountain glaciers, tropical glaciology

\section{INTRODUCTION}

Globally, glacier meltwater provides water resources for some of the most populated regions on Earth (Barnett and others, 2005). Understanding the driving processes behind meltwater generation is necessary for accurate prediction of water resource availability. While there have been many significant advances in process understanding (e.g. Hock, 2005) that are being incorporated into glacier melt models, most of these investigations and modeling efforts have been for glaciers at mid- to high- latitudes (e.g. Pellicciotti and others, 2014). By comparison, low latitude glaciers in the tropics are understudied due both to their remoteness and high altitude. In the last 20 years, glaciers located in the tropics have gained interest and have been studied at a few well instrumented sites, such as the Zongo Glacier, Bolivia (Wagnon and others, 1999a, b; Sicart and others, 2011), the Antisana Glacier, Ecuador (Francou and others, 2004, Favier and others, 2004a, b), Kilimanjaro in Tanzania, (Mölg and Hardy, 2004; Mölg and others, 2008), the Lewis Glacier in Kenya (Nicholson and others, 2010, 2013) and Artesonraju and Shallap in Peru (Kaser and Osmaston, 2002; Winkler and others, 2009; Gurgiser and others, 2013a, b). These studies have shown some of the distinct characteristics of the energy balance of tropical glaciers, such as the importance of negative latent heat fluxes on the energy balance during the dry season (Wagnon and others, 1999b).

To date, one process that has not been explicitly investigated in the scientific literature is the impact of longwave radiation on melting at the lateral margin of tropical glaciers. Based on field observations, it has been noticed that glaciers in mountainous tropical areas seem to retreat not only based on altitude, as a function of air temperature gradients, but also strongly retreat inwards from their lateral margins. This can be seen for the Pastoruri Glacier (Fig. 1), in the Cordillera Blanca (Peru), or the Lewis Glacier (Kenya). Terminal ice cliffs have been investigated by Chinn (1987) and Lewis and others (1998) in Antarctica and by Winkler and others (2010) on Kilimanjaro, but with a focus on the variation of incoming shortwave radiation between the vertical ice cliffs and the flat glacier surface and associated melt.

Surrounding terrain, typically from the valley walls and adjacent mountains, influences the longwave radiation budget and the spatial melt patterns at the glacier surface (Marks and Dozier, 1979; Olyphant, 1986; Gratton and others, 1993; Plüss and Ohmura, 1997; Hannah and others, 2000). These terrain emissions account for a significant increase of longwave radiation in cold and dry atmospheric conditions at high latitude. For example, in northern Canada, longwave radiation from a south-facing snow-free valley (slope $>35^{\circ}$ ) was shown to increase longwave radiation on the opposite slope by up to $60 \%$ (Sicart and others, 2006). Moreover, in the Canadian Rockies, terrain irradiance increased longwave radiation 30-50\% locally, augmenting local melt by $30 \%$ while glacier-wide effects were $<6 \%$ (Jiskoot and Mueller, 2012). The process investigated here is similar to terrain longwave radiation, but 


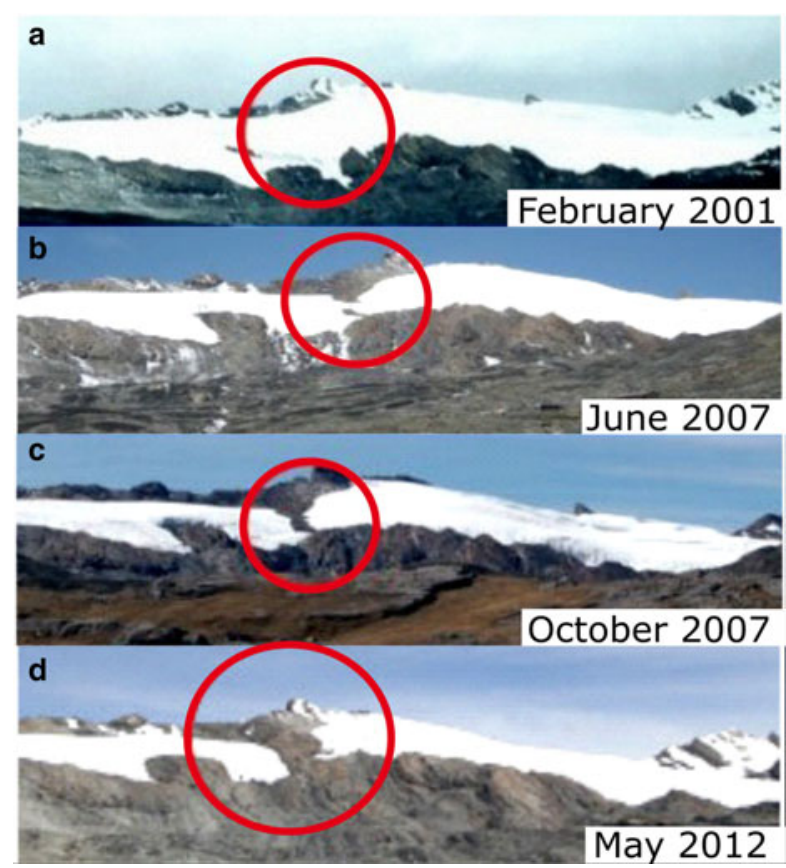

Fig. 1. Pastoruri Glacier fragmenting in two distinct sections in 2007. Images obtained from the Sociedad Peruano de Drecho Ambiental (a, b, c) and from D. Hoffman (d).

focused on a smaller scale, where only the terrain up to $15 \mathrm{~m}$ away of the glacier impacts the first few meters of the ice (Benn and Evans, 2010).

A comparable process to the margin melt is backwasting from ice cliffs on the debris-covered glacier (Sakai and others, 1998, 2002; Han and others, 2010; Reid and Brock, 2014; Steiner and others, 2015; Buri and others, 2016). Ice cliff backwasting, which happens when an exposed ice face on the glacier receives increased longwave emission from the surrounding debris, can be an important contributor to overall ablation (Gardelle and others, 2013; Pellicciotti and others, 2015; Steiner and others, 2015). We hypothesize that a similar process happens at the glacier margin, where the glacier lateral margin receives enhanced longwave radiation from debris and terrain adjacent to the glacier, and that this process is potentially an important ablation process for tropical glaciers.

The present study investigates the magnitude and spatial variability of the longwave radiation emitted from the rock surface adjacent to a tropical glacier and its impact on the energy balance at the glacier margin and on the total glacier ablation. The longwave flux emitted by the rock adjacent to the glacier is calculated using calibrated groundbased thermal infrared high-definition images of the ablation zone of the Cuchillacocha Glacier, located in the Cordillera Blanca, Peru. The resulting margin longwave flux dataset is incorporated into a distributed energy-balance model of the glacier to assess the relative impact of the longwave flux on the glacier energy balance and melt.

\section{METHODS}

\subsection{Field site and instruments}

The Cuchillacocha Glacier $\left(9^{\circ} 24^{\prime} \mathrm{S}, 77^{\circ} 21^{\prime} \mathrm{W}\right)$, located at the head of the Quilcayhuanca Valley, ranges in elevation from 4700 to 6096 m a.s.l. (Fig. 2).

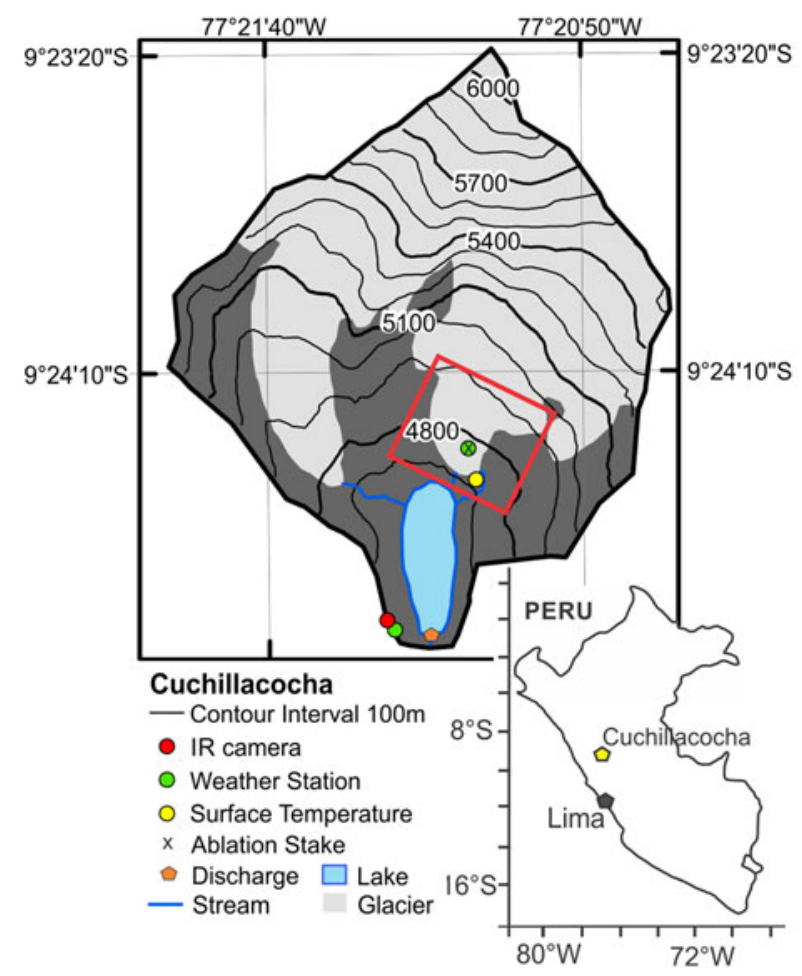

Fig. 2. Map of instrumentation deployed at Cuchillacocha Glacier, Peru. Inset box shows site location within Peru. The red box is the area analyzed in the infrared images. The thick black outline is the watershed boundary. Figure adapted from Aubry-Wake and others (2015).

The field site and instruments used in this study are the same as described by Aubry-Wake and others (2015) with a few additional sensors. An automated weather station (AWS) operated on the glacier ablation zone for the period 23 June to 10 July 2014 at an elevation of $4821 \mathrm{~m}$ a.s.l. It recorded incoming and outgoing shortwave radiation, net radiation, air temperature and relative humidity at 0.2 and $1.0 \mathrm{~m}$ above the ice level, and surface temperature using an infrared thermocouple sensor with a surface area of $0.5 \mathrm{~m}^{2}$ at $1 \mathrm{~min}$ time intervals (Supplementary Fig. S1). Twelve ablation stakes were also deployed within $10 \mathrm{~m}$ of the weather station.

Thermal infrared images were taken at 5-10 min intervals for a total of $33 \mathrm{~h}$ between 23 and 25 June 2014. The thermal infrared camera was located at an elevation of $4645 \mathrm{~m}$ a.s.l. on a moraine facing the glacier, $945 \mathrm{~m}$ away from the toe of the glacier and $1145 \mathrm{~m}$ from the AWS. The infrared camera, a Jenoptik VarioCam HD with a resolution of $1024 \times 768$, utilizes an uncooled microbolometer and has a spectral range covering the thermal infrared wavelength of $7.5-14 \mu \mathrm{m}$, with a manufacturer's stated accuracy of $\pm 1.5^{\circ} \mathrm{C}$. Pixels for the ablation zone have a $0.64 \mathrm{~m}^{2}$ mean resolution. Air temperature and humidity were recorded at the location of the thermal infrared camera.

At the lowest elevation point along the glacier margin, four temperature sensors were placed at distances of $1,3,7$ and $10 \mathrm{~m}$ from the ice margin. The edge sensors were at the ground surface, under small piles of rocks to maximize the thermal contact between the sensor and the ground. As the sensors were positioned at ground level, their measured temperature is assumed as the 'true' surface temperature. The glacier meltwater runs into Cuchillacocha Lake. 
The discharge from the lake was measured using standard pressure transducer instrumentation. Supplementary Table S1 further describes the instruments deployed at the field site.

The ground-based infrared images were converted to calibrated surface-temperature data following the methodology of Aubry-Wake and others (2015). The thermal infrared camera measures radiance, which is a function of the surface temperature, the emissivity of the measured surface and atmospheric transmissivity. Using Plank's law, the radiance is converted to surface temperature. The image processing methodology requires air temperature and relative humidity at the infrared camera location and the glacier AWS, as well as a minimum of three surface temperature control points. These are used to account for interference from the atmosphere and the surroundings, such as reflected radiation from the mountains, turbulent eddies or variable sun exposure. The resulting thermal infrared imagery is a high-resolution, gridded temperature dataset that allows the investigation of small-scale temperature variations at the ground and glacier surfaces.

\subsection{View factors}

The calculation of the longwave radiation transfer from the rock surface adjacent to the glacier to the ice margin accounts for the geometry of the ice margin using view factors. A view factor is the proportion of the radiation leaving a surface and reaching another surface (Johnson and Watson, 1984). At the glacier margin, this corresponds to the amount of longwave radiation that reaches the ice face from the adjacent ground surface, which is composed of rock debris of various sizes and sections of exposed bedrock. To define the distance of influence of the ground surface onto the glacier margin, theoretical view factors for $1 \mathrm{~m}$ increments leading away from the ice margin are calculated. For each meter away from the margin, a geometric derivation of the view factors, $g v f$, is calculated (Johnson and Watson, 1984) (Eqn (1)).

$$
g v f(x)=1-0.5\left(x /\left[x^{2}+H^{2}\right]^{1 / 2}-1\right)
$$

where $x$ is the horizontal distance from the top of the glacier slope to the measurement point, here done for $1 \mathrm{~m}$ increments from the glacier edge and $H$ is the height of the glacier in meters. The height of the glacier $\mathrm{H}$ and the horizontal distance from the top of the slope to the edge of the glacier face $A$ are obtained from the observed geometry of the glacier (Fig. 3). The $g v f$ is obtained as the difference between a fully-unobstructed sky and the calculated sky view factor.

Terrain that is farther from the glacier than a view factor of 0.01 (i.e. $<1 \%$ of the longwave radiation emitted by the rock is reaching the glacier margin), is considered to have negligible influence on the longwave flux from the rock adjacent to the glacier. Based on a DEM (10 cm resolution) of the ablation zone obtained from UAV data (Wigmore and Mark, 2017), the glacier margin wall length $(L)$ in the ablation zone was found to be consistently $\sim 3.0 \mathrm{~m}$ long with an inclination $\theta$ varying from $30^{\circ}$ to almost $90^{\circ}$ and most frequently being $75^{\circ}$. Based on this consistently observed margin geometry, this analysis assumes that the glacier margin is uniform in height, with the glacier margin geometry being a wall length $(L)$ of $3 \mathrm{~m}$ at an angle of $75^{\circ}$. Our view

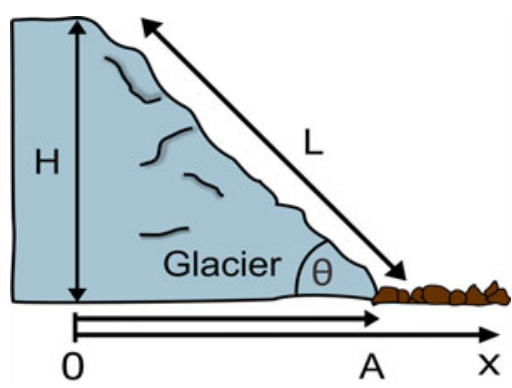

Fig. 3. Schematic of view factor calculation. $H$ is the height of the glacier face, $x$ is the distance from the edge of the glacier to the measurement point, $A$ is the horizontal distance from the top of the slope to the edge of the glacier face and $L$ is the length of the glacier face.

factor calculation also assumes that surface topography adjacent to the glacier is uniform and flat in the area of interest. Actual ground topography along the edge of the glacier varies slightly from this ideal representation with the presence of boulders, debris mounds or fallen ice blocks. However, we consider that these local variations (boulders, local depression, ice blocks) average each other out when a larger area is taken into consideration (Reid and Brock, 2014).

The glacier view factor decreases exponentially with increasing distance from the glacier. Past a critical distance from the glacier margin, the energy emitted by the rock effectively does not reach the glacier and is instead entirely transferred to the atmosphere. For the glacier edge configuration of a glacier margin face $3 \mathrm{~m}$ long at an angle of $75^{\circ}$, the glacier view factor is 0.28 for the first meter away from the glacier margin, then decreases to 0.19 for the second meter and reaches 0.05 at a distance of $5 \mathrm{~m}$ from the edge. At a distance of $15 \mathrm{~m}$ from the glacier margin, the view factor is slightly below the 0.01 threshold.

\subsection{Margin longwave radiation flux calculation}

Using the surface temperature dataset obtained from processed ground-based infrared imagery (Aubry-Wake and others, 2015), the rock surface temperature was extracted for 15 one-meter increments perpendicular to the glacier edge at 350 discrete locations along the ablation zone margin. For each meter step along the transect, the longwave radiation reaching the glacier is calculated using the StefanBoltzmann Law. The longwave radiation is then summed for the $15 \mathrm{~m}$ transect and divided by the length of the glacier wall $L$ to obtain the longwave radiation reaching the glacier margin from the adjacent rock:

$$
L W_{\text {margin discrete }}=\sum_{x=15}^{x=1}\left(g v f_{x} \varepsilon \sigma T_{x}^{4}\right) / L
$$

where $\varepsilon$ is the emissivity of the surface $(0.9), \sigma$ is the Stefan Boltzmann constant $\left(5.67 \times 10^{-8} \mathrm{~W} \mathrm{~m}^{-2} K^{-4}\right), T$ is the surface temperature $(K)$ extracted from the thermal infrared images, $x$ is the distance away from the glacier margin and the resulting $L W_{\text {margin discrete }}$ is in $\mathrm{W} \mathrm{m}^{-2}$. The longwave margin flux $L W_{\text {margin }}$ is obtained from the average of all $350 L W_{\text {margin discrete }}$ calculation along the ablation zone. Eqn (2) is also used to compute the longwave margin flux 
from the surface temperature of the edge sensors for a 14-day period.

\subsection{Estimation of the $L W_{\text {margin }}$ flux impact on glacier ablation}

The impact of the $L W_{\text {margin }}$ flux on the ice ablation at the glacier margin is estimated by using a distributed glacier energy-balance model run at an hourly time step with a $30 \mathrm{~m} \times 30 \mathrm{~m}$ grid cell resolution. Two versions of the model were used: a base model which is a modified version of the one developed by Rigaudiere and others (1995) for the Zongo glacier in Bolivia and a modified version of that model that integrates the $L W_{\text {margin }}$ flux in the energy balance at the glacier margin. The difference between the simulation results of the two model versions was used for estimating the ablation triggered by the $L W_{\text {margin }}$ flux.

\subsubsection{Base model}

The base model solves the following energy-balance equation:

$$
M=S W_{\text {net }}+L W_{\text {net }}+H+L E-C
$$

where $S W_{\text {net }}$ is the net incoming shortwave radiation, $L W_{\text {net }}$ is the net longwave radiation, $H$ and $L E$ are the turbulent sensible and latent heat flux respectively, $C$ is the conductive heat flux and $M$ is the energy available for melt. All terms are in $W \mathrm{~m}^{-2}$. A detailed description of equations and parameters is presented in the Supplemental materials.

Input parameters are extrapolated for each cell at an hourly time step from measurements made at the AWSsituated on the glacier. Those include the air temperature measured at two levels $(1.0$ and $0.2 \mathrm{~m}$ above the ice level), the relative humidity, the wind speed and the incoming solar radiation and the atmospheric pressure. Air temperature is extrapolated using a lapse rate of $0.55^{\circ} 100 \mathrm{~m}^{-1}$ (Gurgiser and others, 2013a). For simplicity, wind speed and relative humidity are assumed to remain constant across the entire glacier. Considering the short distance between the glacier margin and the AWS $(200 \mathrm{~m})$, these simplifications were considered reasonable. Direct solar radiation is estimated using the method proposed by Ohta (1994) and Fierz and others (1997). The method uses the theoretical maximum solar radiation $I_{\mathrm{c}}$ (Garnier and Ohmura, 1968) calculated at each cell as follows:

$$
S W_{\text {in }}=\frac{S W_{\text {meas }}}{I_{\text {CAWS }}} I_{\mathrm{C}}
$$

where $S W_{\text {in }}$ represents the incoming solar radiation for a given cell, $S W_{\text {meas }}$ represents the incoming solar radiation measured at the AWS and $I_{\text {CAWS }}$ is the theoretical clear-sky solar radiation calculated for the cell that hosts the AWS. The theoretical maximum solar radiation $I_{\mathrm{c}}$ calculation includes the terrain effects of the slope and angle of the model grid cell. This also accounts for cloudiness effect, as the calculated incoming solar radiation for each grid cell is scaled to the ratio of measured incoming solar radiation $S W_{\text {meas }}$ to the potential clear-sky radiation $I_{\text {CAWS }}$.

$S W_{\text {net }}$ is obtained using $S W_{\text {in }}$ and a constant albedo throughout the simulation. This is motivated by the short duration of the simulation ( 2 weeks) and by the fact that no significant precipitation was recorded prior to and during the experiment. Albedo was assigned to individual cells based on their surface type as identified on digital pictures. Albedo of clean dry snow is 0.8, firn at the snow/ice transition is 0.55 , clean ice is 0.4 , dirty ice at the toe of the glacier is 0.15 and intermediates between clean and dirty ice is 0.3 (Cuffey and Paterson, 2010).

Shade from the surrounding topography may have a great influence on melt generation because incoming solar radiation is the most important source of energy for tropical glacier melt (Nicholson and others, 2013) and the annual sun path variation is limited in the tropic compared with temperate locations. Where the ice surface is consistently in the shadow of the surrounding mountains, the energy received is significantly reduced. For example, this situation is observed from the positioning of the small tropical glacier, often located in areas of persistent shadows below cliff bands (Kaser and Osmaston, 2002). To account for this phenomenon, a filter based on the topography of the area surrounding the Cuchillacocha Glacier is used in both model versions. The filter modulates the incoming solar radiation received at the surface of the glacier. For each time step, the sun position relative to the studied cell is calculated using sun elevation and azimuth. Where the topography obstructs the incoming solar radiation vector, $S W_{i n}$ is turned to $15 \%$ of the incoming solar radiation to account for diffuse radiation (Hock and Noetzli, 1997) for the cell. Otherwise, $S W_{i n}$ is unchanged.

In the base model, the net longwave radiation $L W_{\text {net }}$ is calculated as follows:

$$
L W_{\text {net }}=L W_{\text {in }}-L W_{\text {out }}
$$

where $L W_{\text {in }}$ and $L W_{\text {out }}$ are the longwave radiation fluxes to and from the glacier surface respectively. Both fluxes are estimated using an empirical equation derived from the Stefan-Boltzmann law (Rigaudiere and others, 1995). The atmospheric emissivity for $L W_{\text {in }}$ was calculated using Brutsaert (1975) while the ice emissivity is 0.985 for $L W_{\text {out }}$.

The turbulent fluxes $H$ and $L E$ are calculated using the Richardson stability coefficient (Kustas and others, 1994). Because the wind speed is only measured at one level the following assumptions are made:

- For $\mathrm{H}$ calculation, the wind at $0.2 \mathrm{~m}$ above the ice surface is $30 \%$ of the one measured at $1.0 \mathrm{~m}$.

- For $L E$ calculation, the wind speed at $1 \mathrm{~cm}$ is zero. Relative humidity is supposed to remain constant between 0.01 and $1.0 \mathrm{~m}$.

The conductive heat flux $C$, is calculated for the top $1.5 \mathrm{~m}$ of the ice. Underneath this ice layer the ice temperature is assumed to remain at the annual average air temperature. The ice surface temperature is hypothesized to be at the air temperature if the air temperature is negative and at $0^{\circ} \mathrm{C}$ if the air temperature is at or above $0^{\circ} \mathrm{C}$. The $1.5 \mathrm{~m}$ top ice layer is divided into five homogeneous sublayers. The conductive heat flux is then computed for each sublayer from the change in cold content with time (Hock, 2005).

The energy available for melt, $M$, is calculated using Eqn (3). It is converted into melt volumes by using the latent heat of melt.

\subsubsection{Modified model}

In the modified model, the cells situated at the edge of the glacier in the base model are divided into two sub-cells. 
Only cells in the area analyzed in the infrared images (see Fig. 2) are affected by the modification. The first sub-cell, having an area $10 \%$ of the original cell surface, represents the glacier wall $(L)$ described in Section 3.2. For this subcell, the modified model is applied. For the second subcell, representing $90 \%$ of the original cell surface, the model simulate melt using the same energy balance as the base model. In the modified energy-balance equation, the $L W_{\text {net }}$ term is replaced by $L W_{\text {net margin }}$ that is calculated as follows:

$$
L W_{\text {net margin }}=L W_{\text {in }}-L W_{\text {out }}+L W_{\text {margin }}
$$

where $L W_{\text {margin }}$ corresponds to the longwave radiation flux from the ground surface adjacent to the glacier. For practical reasons, all margin sub-cells receive the same value for $L W_{\text {margin }}$ at each time step. The value corresponds to the hourly average off all $L W$ calculated at Section 3.3 with Eqn (2).

\subsection{Base model performance evaluation}

The model performance is evaluated in two ways. First, simulated ice cumulative ablation at the AWS cell is compared with ablation measured using ablation stakes. Second, the cumulative melt simulated for all the glacier cells is compared with the cumulative discharge measured at a gauging station situated at the Cuchillacocha Lake outlet (see Fig. 2).

\subsubsection{Ablation measurements}

Twelve ablation stakes were deployed in an area of $\sim 10 \mathrm{~m}^{2}$ around the AWS for the 14-day observation period. The average measured ablation of the 12 stakes is used for comparison to the cumulated ablation simulated at the same model cell location. The average ablation measured for the study period was $12 \mathrm{~cm}$ with a standard deviation of $3 \mathrm{~cm}$, with individual measurements ranging from 9 to $19 \mathrm{~cm}$. The modeled cumulative ablation simulated with the base model at the AWS cell was $18 \mathrm{~cm}$. Simulation results are within the measurement range with a possible tendency for overestimation. Considering the uncertainty and range of the measurements, the difference between the cell size and the measurement area, and considering that the model results are used in comparison with the modified model simulation only, those results are considered acceptable for the study.

\subsubsection{Melt volume measurements}

The base model is evaluated by comparing cumulative simulated melt, the output of the melt model, with the measured melt, which is the sum of the measured cumulative lake discharge and calculated lake evaporation. This comparison is made under the assumption that the totality of the melt that occurs at the cells surface drains into the proglacial lake and that the only water losses in the system occur through lake evaporation. Evaporation is calculated using the Penman equation (Abtew and Malesse, 2013), using coefficients from Delclaux and others (2007), who calibrated the Penman Equation for Lake Titicaca. The calculated evaporation to measured discharge ratio is 0.14 . The comparison between the cumulative simulated melt and the measured melt is presented in Figure 4. The cumulative simulated melt is obtained by first converting the energy available for melt to $\mathrm{m}$ w.e. for each glacier cell using a latent heat of fusion of $333.6 \mathrm{~J} \mathrm{~g}^{-1}$ and an ice density of $920 \mathrm{~kg} \mathrm{~m}^{-1}$ and then summing all cells to obtain glacierwide melt.

The daily simulated melt with the base model from the glacier has an amplitude of $1500 \mathrm{~m}^{3} \mathrm{~h}^{-1}$, from zero at night to a peak melt at noon, which results in pronounced daily steps in the cumulated values. The estimated melt, obtained from the measured lake discharge and calculated lake evaporation, does not show these daily steps as both discharge and evaporation have relatively small daily amplitude variations. The lake discharge varies between 302 and $422 \mathrm{~m}^{3} \mathrm{~h}^{-1}$ and the evaporation between 26 and $173 \mathrm{~m}^{3} \mathrm{~h}^{-1}$. This explains the difference in the pattern of the two lines on Figure 4.

With a correlation coefficient (Pearson's $R$ ) of 0.74 , simulated and measured melt volumes, shows an acceptable ability of the base model to reproduce melt volumes during the comparison period. Total cumulative melt volumes at the end of the simulation differ by $13 \%$ (Fig. 4), suggesting the model is able to provide a reasonable representation of melt volumes for the purpose of the study.

\section{RESULTS}

\subsection{Spatial variability of margin longwave flux}

The margin longwave flux obtained from the infrared images shows a strong daily cyclicity (Fig. 5) over the $33 \mathrm{~h}$ of available thermal infrared imagery. The average longwave flux for the ablation zone margin, $L W_{\text {margin, }}$ varies between $85 \mathrm{~W} \mathrm{~m}^{-2}$ at 6:00 AM, the coldest time of the day, and $108 \mathrm{~W} \mathrm{~m}^{-2} \sim 12: 00 \mathrm{PM}$ (noon), the warmest time of the day. It shows a slow cooling trend overnight, decreasing only by $8 \mathrm{~W} \mathrm{~m}^{-2}$ between 6:00 PM and 8:00 AM. The longwave margin flux increases quickly when the sun appears, reaching $107 \mathrm{~W} \mathrm{~m}^{-2}$ between 8:00 and 10:00 AM. It then stabilizes until 12:00 PM, the end of the study period.

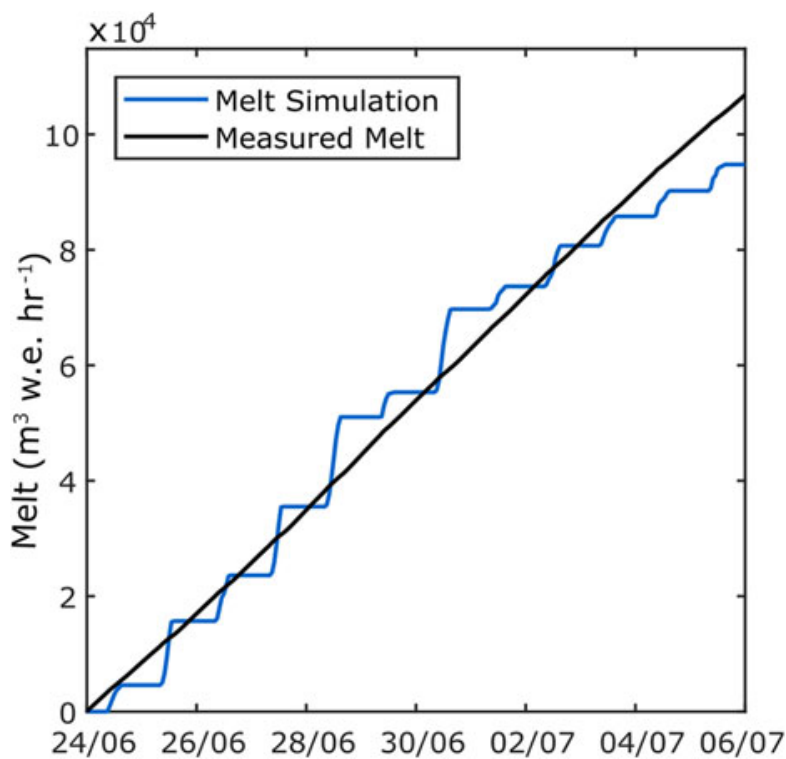

Fig. 4. Comparison of simulated and measured cumulative glacial melt. The blue line is the simulated cumulative melt volume from the base model and the black line is the measured melt (i.e. the sum of the lake discharge and calculated lake evaporation). 

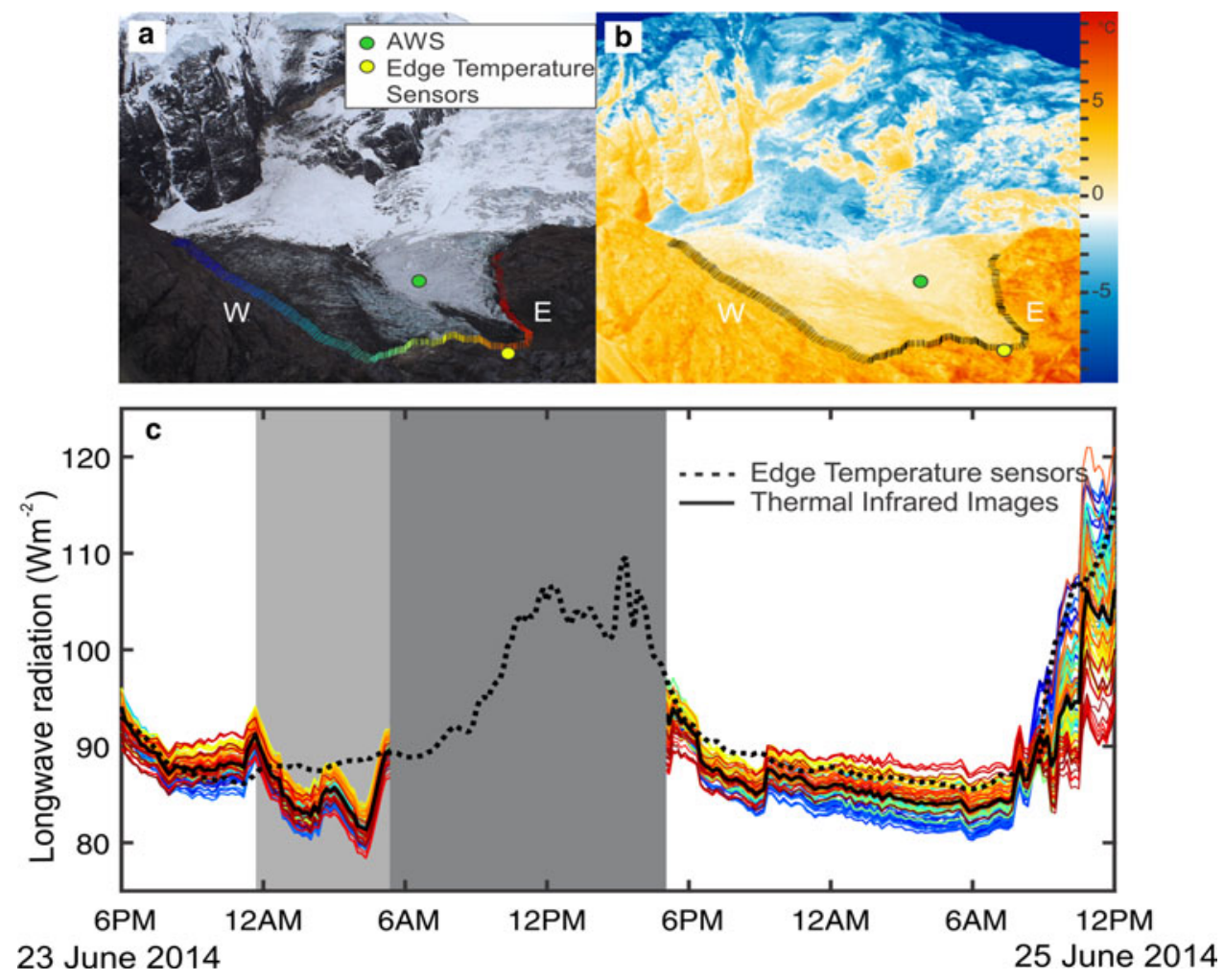

Fig. 5. Spatial variation of $L W_{\text {margin. }}$. Each colored line on (a) is a location where surface temperature was extracted from the thermal infrared images for the $33 \mathrm{~h}$ of available imagery, at 5-10 min intervals. The same locations are thin black lines on the infrared images in (b). In (a) and (b), the green dot is the AWS, the yellow dot is the location of the edge temperature sensors and the $W$ and $E$ represent the west and east side of the ablation zone. In (c) each colored line is the $L W_{\text {margin discrete }}$ at the corresponding color location in (a). The dashed black line is the longwave radiation calculated at the glacier margin with the edge temperature sensors and the thick black line is $L W_{\text {margin, }}$ the average margin longwave flux from all the locations along the ablation zone from the infrared images. Only every third transect from (a) is shown for clarity. The light grey overlay delineates when weather conditions interfered with measurements and the dark grey overlay is when instrument malfunction prevented thermal infrared image acquisition.

The entire ablation margin shows a similar daily fluctuation in $L W_{\text {margin discrete, }}$ but the amplitude of daily pattern of the flux depends on the location along the glacier margin. At night, the north side of the glacier (blue on Fig. 5a) is colder, with a longwave flux ranging between 80 and $85 \mathrm{~W} \mathrm{~m}^{-2}$. For the same period, the west side of the ablation zone (red on Fig. 5a) emits slightly more longwave radiation, between 87 and $92 \mathrm{~W} \mathrm{~m}^{-2}$. During the day, the opposite pattern happens: the east side of the glacier emits up to $115 \mathrm{~W} \mathrm{~m}^{-2}$, but the west side reaches only $\sim 92$ $100 \mathrm{~W} \mathrm{~m}^{-2}$. On average, the difference between the east and west sides of the glacier is $7 \mathrm{~W} \mathrm{~m}^{-2}$ overnight, and increases to $28 \mathrm{~W} \mathrm{~m}^{-2}$ during the day. Both sides of the glacier lie at the same altitude, and thus, the difference in longwave radiation is not related to elevation change. Instead, it appears that the spatial variability of the margin longwave flux is due to local shading effects. Local shading on the ablation zone, obtained from the topography filter in the model (see Section 3.4.1.), shows that in the morning, the east side starts receiving shortwave radiation early in the day (slightly past 8:30 AM) but the west side stays in the shade until past 9:00 AM. In the afternoon, the opposite situation occurs. At 3:30 PM, the west side of the glacier is still in the sunlight and only becomes shaded slightly before 5:00 PM (Fig. 6). Those shading effects have a direct influence on the temperature of the rock adjacent to the glacier affecting the longwave margin flux explaining the variation between the $L W_{\text {margin discrete }}$ on the east and west side of the ablation zone.

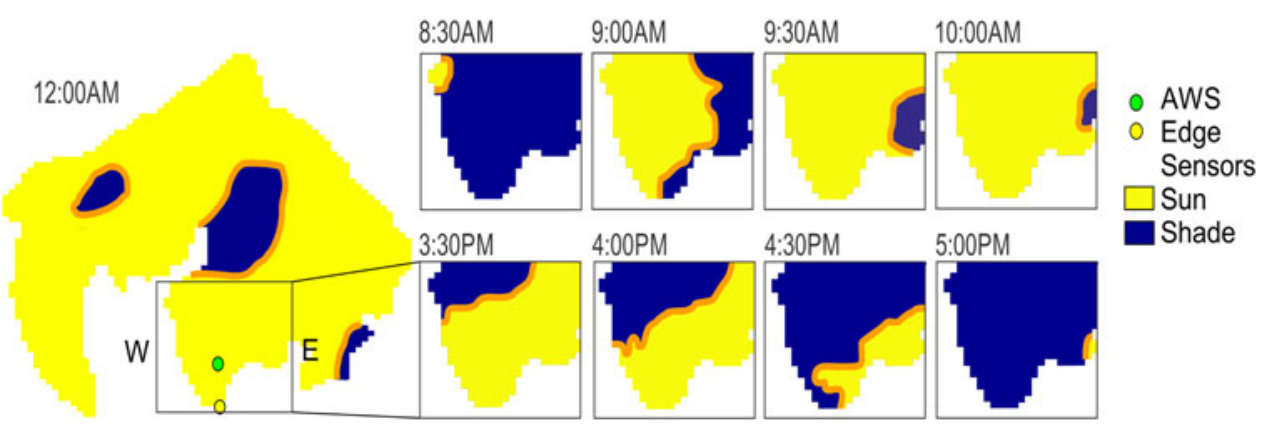

Fig. 6. The shading on the ablation zone for morning and afternoon. Blue is shaded, yellow is receiving incoming solar radiation and orange is the transition zone. $E$ and $W$ represent the east and west sides of the ablation zone. 


\section{2. $L W_{\text {margin }}$ extrapolation in time}

For logistical reasons, the infrared images were collected over $33 \mathrm{~h}$ only. The measurements are extrapolated to a 14 day period by using the longwave flux calculated from the edge temperature sensors measurements (Fig. 7).

A simple model uses linear regression on the margin longwave fluxes calculated from the temperature edge sensors (black dashed line on Fig. 7) and from the longwave flux calculated from the infrared thermal images (black line on Fig. 7) for the $33 \mathrm{~h}$ when both measurements overlap. The longwave flux calculated from the infrared thermal images is the average of the 350 discrete longwave calculations along the glacier margin (Eqn (2)). This linear regression model results in a spatially-averaged longwave margin flux for the 14 days period (red line on Fig. 7). The resulting correlation coefficient (Pearson's R) between the longwave margin flux calculated from the edge temperature sensors and the infrared images is 0.92 .

Over the study period, the margin longwave flux fluctuates from a minimum of $85 \mathrm{~W} \mathrm{~m}^{-2}$ to a maximum of $112 \mathrm{~W} \mathrm{~m}^{-2}$. The daily pattern consistently shows a sharp increase in the morning, starting as soon as the incoming solar radiation reaches the glacier, $\sim 8: 00 \mathrm{AM}$ and either peak $\sim 12: 00 \mathrm{AM}$, or fluctuate $\sim 100 \mathrm{~W} \mathrm{~m}^{-2}$ until mid-afternoon, due to cloud cover throughout the day. The margin longwave flux then decreases sharply between 4:00 PM and 5:00 PM and then gradually reaches its minimum at 6:00 AM.

\subsection{Impacts on surface energy balance}

Figure 8 shows the energy available for melt for all the glacier cells as simulated by the modified model for the first day of the experiment. The figure clearly shows an enhanced melt condition at the glacier margin as compared with nonmargin areas. The margin regions receive a higher energy available for melt $M$ of $\sim 100 \mathrm{~W} \mathrm{~m}^{-2}$ between 11:00 AM and 5:00 PM compared with the regions situated away from the margin.

At 10:00 AM, when the glacier starts exhibiting melt areas, the influence of $L W_{\text {margin }}$ is not as strong as later on during the day but still perceivable. At 5:00 PM, the model calculates that cells at glacier margin only receive enough energy to generate some melt as all the cells situated away from the margin have zero energy available for melt. The energy available for melt varies along the ablation zone margin, with the highest values observed at the lower portion of the glacier. As the $L W_{\text {margin }}$ value was identical for all cells at each time step, the variability seen along the glacier margin results from other factors such as the spatial distribution of the topographic shading, the elevation and/or the albedo.

A comparison of the models' output for the grid cells at the glacier margin for the 14-days is in Figure 9. Figure 9a shows that the introduction of $L W_{\text {margin }}$ into the modified model leads to higher energy for melt during the day but not overnight. Around midday, when energy available for melt is at its maximum for most of the days, the extra energy for melt calculated by the modified model reaches $20 \%$ more than that calculated by the base model. The average value for the 10:00 AM to noon window reaches $310 \mathrm{~W} \mathrm{~m}^{-2}$ for the modified model against $200 \mathrm{~W} \mathrm{~m}^{-2}$ for the base model. The difference between the model outputs is not only observed in the amplitudes of the energy availability for melt but appears in timing too. For at least 10 days out of the 14 simulation days, the energy available for melt remains above zero in the modified simulations for an at least $1 \mathrm{~h}$ longer than the base model. On average, the extra energy available for melt for the 4:00-6:00 PM time window is $30 \mathrm{~W} \mathrm{~m}^{-2} \mathrm{~h}^{-1}$ higher with the modified model than the base model. The situation at the beginning of the day has similar characteristics to the evening but the difference between simulations is less pronounced. The net radiation at the glacier margin presented in Figure 9b exhibits variations that are very close to the ones of the energy for melt. This confirms the importance of the shortwave and longwave radiation fluxes in tropical glacier ablation control. During the night, the net radiative flux typically reaches an average of $-90 \mathrm{~W} \mathrm{~m}^{-2}$ for the base model, compared with $-6 \mathrm{~W} \mathrm{~m}^{-2}$ when simulated using the modified model. This difference shows that the base model requires a significant energy input to reach a positive energy balance at the start of the day, but the modified model needs minimal input to have energy available for melt.

Overall, Figure 9 shows that cumulated on the length of the experiment, the extra energy for melt computed by the modified model compared with the base model reaches $37.4 \pm 5.6 \times 10^{6} \mathrm{~W} \mathrm{~m}^{-2}$ with a $15 \%$ uncertainty value based on Machguth and others (2008), who suggest an uncertainty for cumulative mass-balance modeling of $10 \%$. Considering this estimate conservative, we use a value of $15 \%$ to calculate our uncertainties. Using a latent heat of

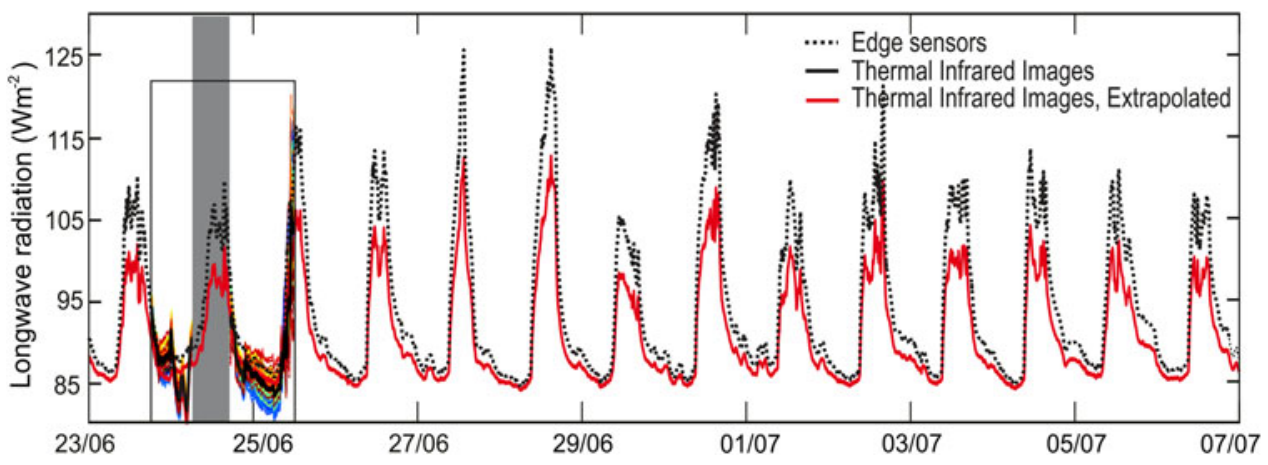

Fig. 7. Extrapolated $L W_{\text {margin }}$ (red) from 23 June 2014 to 7 July 2014 , based on the linear regression model between the measurements with the infrared images (black) and the edge temperature sensors (dashed black). The square inset is the period where the infrared camera was active.

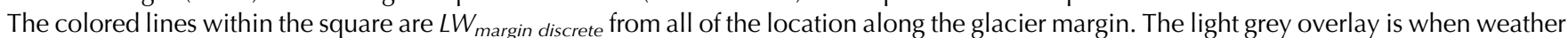
conditions interfered with measurements and the dark grey overlay is when instrument malfunction prevented thermal infrared image acquisition. 


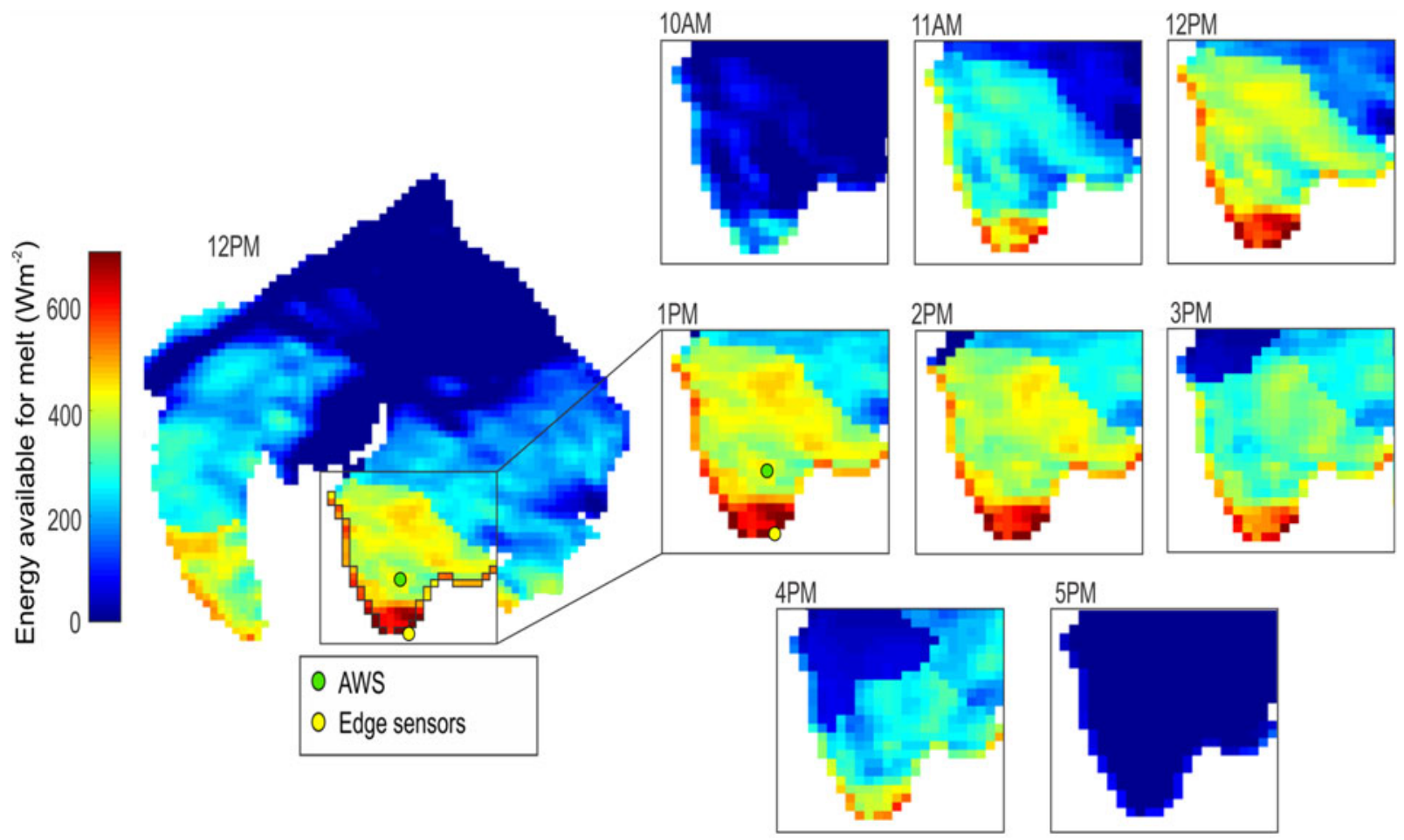

Fig. 8. Energy available for melt $M$ from the modified melt model for 23 June 2014. For visualization purposes, the area impacted by the $L W_{\text {margin, }}$ which corresponds to only $10 \%$ of the cell on the glacier margin (black outline), was shown as regular sized cells. The green dot is the AWS and the yellow point is the edge sensors location. Only the times when energy available for melt is above zero are shown.

fusion of $333.6 \mathrm{~J} \mathrm{~g}^{-1}$ and an ice density of $920 \mathrm{~kg} \mathrm{~m}^{-1}$, this cumulated extra energy for melt corresponds to $12.2 \pm$ $1.8 \mathrm{~cm}$ of ice ablation for the margin cells. For the length of the dry season, from May to October, this value represents an extra ablation of $1.7 \pm 0.3 \mathrm{~m}$ at the glacier margin compared with a simulation where the $L W_{\text {margin }}$ flux is not accounted for. However, this extra seasonal ablation should be considered as a first estimate because the $L W_{\text {margin }}$ flux is likely to vary throughout the season.

In terms of volume, the modified model computes an extra melt volume of $1361 \mathrm{~m}^{3}$ w.e. at the glacier margin over the 14 day simulation period. Because only one of the two glacier tongues was simulated with the $L W_{\text {margin }}$ flux, and because both tongues have a comparable length of ablation area margin (Fig. 1), it is hypothesized that the extra melt caused by the longwave margin flux for the entire glacier margin would be approximately doubled. The resulting $2722 \pm 229 \mathrm{~m}^{3}$ w.e., the extra melt from the inclusion of the margin longwave flux, represents an increase of $2.7 \pm$ $0.2 \%$ of the total glacier melt simulated by the base model over 14 days.

\section{DISCUSSION}

\section{1. $L W_{\text {margin }}$ flux influence on tropical glaciers ablations}

This study is a first attempt at quantifying the energy transfer happening at the glacier margins and its effects on ablation for tropical glaciers. We calculate an order of magnitude
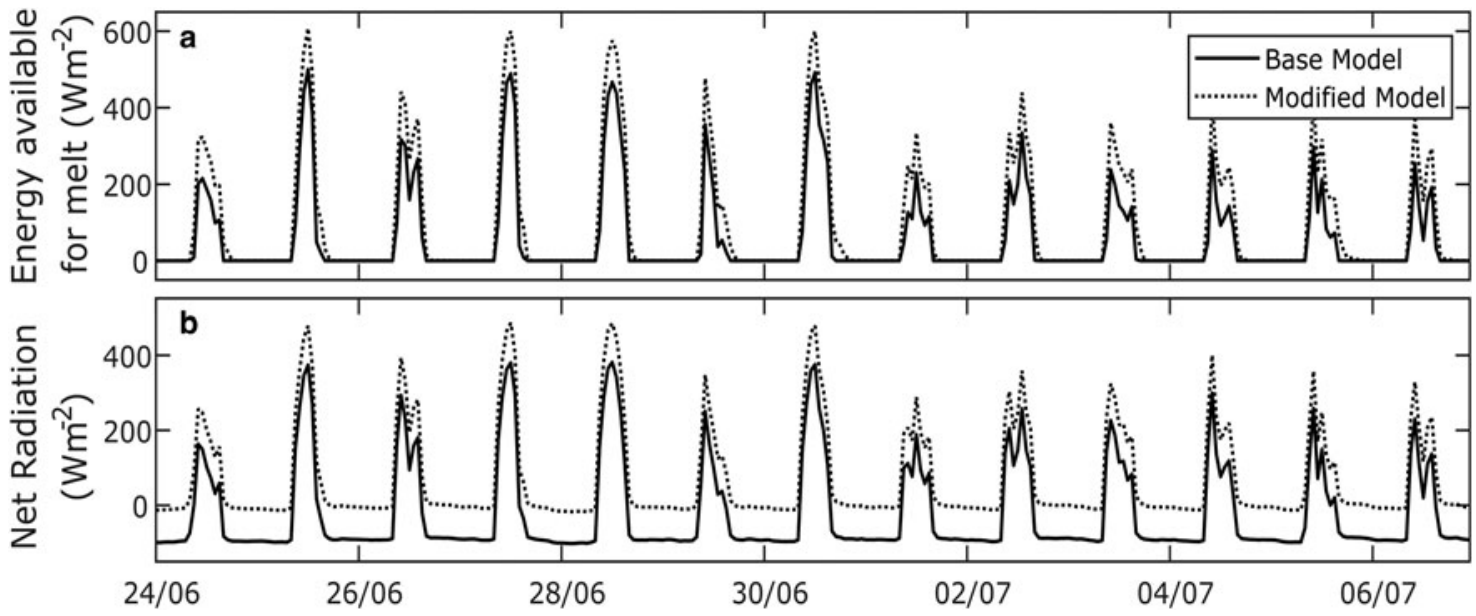

Fig. 9. Modeling results for the base and modified models for the cells at the glacier margin, with (a) the average energy available for melt and (b) the cells average net radiation. 
estimate for both important parameters and show that the longwave margin flux is a significant energy input for the ablation pattern at the glacier margin. Based on our results, this local energy flux should be considered as partly responsible for the strong lateral retreat pattern seen on tropical glaciers.

Moreover, as tropical glacier retreat, the ratio of glacier margin to ablation zone should increase, which will enhance the importance of the margin processes in a positive feedback. The feedback would only occur as long as the glacier margin has a steep slope angle or is adjacent to steep topography, which is likely as glacier margin ice cliffs have been known to maintain a steep slope angle and to persist over multiple years (Reid and Brock, 2014).

It is likely that other local processes, such as warm air advection, are also factors resulting in enhancing melt at the margin. The calculations and results presented here for the longwave margin flux, based on distributed surface temperature measurements, should be considered as one plausible explanation to this retreat pattern and not as a complete picture of the physical processes happening at the glacier margin.

\subsection{Comparison with ice-cliff backwasting}

No literature was found that studied specifically the impact of longwave radiation from adjacent terrain to a glacier margin of a tropical glacier, but a useful comparison can be made with the study of ice-cliff backwasting on debris-covered glaciers. Our results on the importance of the margin longwave flux at the glacier edge are consistent with the result from Steiner and others (2015). Steiner used a point-model of ice cliff backwasting on the debris-covered Lirung Glacier in the Himalayas and found that the longwave flux emitted by the adjacent debris to the ice surface was a significant input to the melt and compensated the deficit between incoming longwave radiation from the atmosphere and outgoing longwave emissions from the ice. The longwave flux from the debris calculated in his study ranges from 40 to $100 \mathrm{~W} \mathrm{~m}^{-2}$ depending on the season. Also on Lirung Glacier, Buri and others (2016) used a fully-distributed, grid-based model to calculate a mean hourly debris longwave flux of $70-80 \mathrm{~W} \mathrm{~m}^{-2}$, varying on the cliff and on the season and contributed to $\sim 25 \%$ of the incoming longwave at the ice cliff. Both of these findings are in the same order of magnitude as the margin longwave flux calculated in this study, which varies from 80 to $120 \mathrm{~W} \mathrm{~m}^{-2}$ and contributes to $29 \%$ of the incoming longwave radiation at the glacier margin.

A comparison of the contribution to glacier-wide melt from ice-cliff backwasting and from the margin longwave flux is more difficult. The backwasting studies have focused on debris-covered glaciers, which show less surface ablation than a glacier with an exposed ice surface and therefore will have a higher proportion of their total ablation coming from exposed ice cliffs. Moreover, the studied glaciers are in different climate regions than our study in the tropical Andes. In the Alps, Reid and Brock (2014) found that the ice cliffs on the Miage Glacier accounted for $1.3 \%$ of the studied area, but contributed a disproportionate $7.4 \%$ of the ablation. At the Lirung Glacier, ice cliff backwasting for the two studied cliffs account for 0.02 and $0.07 \%$ of the studied area but contribute to 0.27 and $0.96 \%$ of the total melt. In the approach used in this study, we only calculate the increase in melt due to margin longwave flux and find that $0.3 \%$ of the glacier area is affected by the margin longwave flux, and this contributes to an overall melt increase of $2.7 \%$.

\subsection{Glacier margin geometry}

An important parameter for our study is the glacier margin geometry. The margin geometry is one of the main factors determining the glacier view factors, and thus the magnitude of the energy transfer from the adjacent terrain to the glacier. For our study, the glacier margin geometry was assumed to be consistent along the studied ablation area. This allowed us to use the simplification of constant glacier view factors. However, glacier geometry will vary from glacier to glacier, and can also change along the margin of an individual glacier. To assess for what type of margin geometry the longwave margin flux is the most important, we use a simple sensitivity analysis of the impact of the glacier wall angle on the glacier view factor. The lower the angle of the glacier wall, the shorter the area of influence from the adjacent ground surface (Fig. 10). For a wall angle of $90^{\circ}$, the $15 \mathrm{~m}$ next to the margin will contribute to the longwave flux, with $42 \%$ of the longwave radiation emitted next to the glacier reaching the glacier wall. However, for a wall at $30^{\circ}$, only the first $5 \mathrm{~m}$ adjacent to the glacier will contribute to the margin longwave flux. For a margin angle of only $15^{\circ}$, the view factor immediately adjacent to the ice margin is already at 0.01 . In this case, the emission from the ground adjacent to the glacier will not reach the glacier. The sensitivity analysis considered a changing glacier wall angle on a flat surface, but the same process would happen with a changing ground surface angle. A glacier margin facing a short cliff band or a rising pile of debris would have a high view factor as well. The one situation where the view factors do not allow for a longwave transfer is when the glacier lies at a very shallow angle $\left(15^{\circ}\right.$ or less) to the ground surface. For any other glacier margin geometry, there will be a strong influence from the adjacent terrain contributing to the energy and mass balance at the glacier margin.

\subsection{Model uncertainty}

The ablation estimations used in this study are based on a physically based energy-balance model designed not to require calibration for setting parameters. The model evaluation (Sections 3.5.1 and 3.5.2) shows that the model adequately reproduces measured ablation. Moreover, the

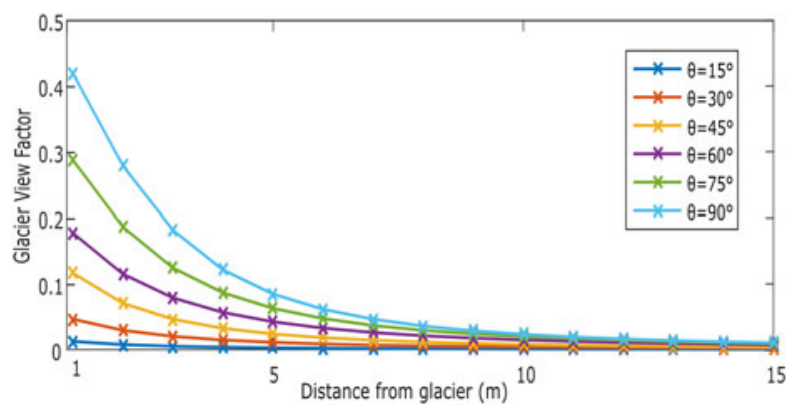

Fig. 10. View factors for different wall angles $\theta$. In this study, the $75^{\circ}$ (green) wall angle is used. A view factor threshold of 0.01 (dashed line) was used to defined areas contributing to margin longwave radiation. 
model's outputs are being used for inter-comparison and are well adapted for the study objectives.

By targeting the main physical processes triggering melt, the model used in this study omits some other processes that may affect its accuracy without affecting significantly its outputs. First, the model does not distinguish directly between direct and diffuse shortwave radiation. When the topography obstructs the direct sunlight, incoming solar radiation to the shaded model cells is set to $15 \%$ of the calculated value without the shading to account for diffuse radiation. This simplification is justified by the assumption that, in our study, the impact of topographic shading on a glacier surrounded by high mountain peaks is more important than the impact of diffused shortwave radiation. In the tropical high Andes during the dry season, with the low relative humidity and the predominantly clear sky, filtering and scattering effects are minimal due to the thin air and the contribution from diffuse sky shortwave radiation is small (Benn and Evans, 2010). The reflected terrain shortwave radiation, another component of diffuse radiation, is considered negligible as the surrounding mountains are composed of dark rock with no snow cover and high sky view factors (Gurgiser and others, 2013a). The importance of topographic shading on incoming solar radiation has been shown in multiple studies. Arnold and others (1996) found that excluding shading increased incoming shortwave radiation by $5.8 \%$ for the Haut Glacier D'Arolla in Switzerland and resulted in an over-prediction of melt in high mountain environment and Brock and others (2010) found a reduction of incoming shortwave of $15 \%$ due to topographic shading on the Miage Glacier in Italy.

Second, the model does not account for topographic longwave irradiance from the surrounding mountains, which Plüss and Ohmura (1997) estimated can cause an error up to $60 \mathrm{~W} \mathrm{~m}^{-2}$ when compared to unobstructed skies and jiskoot and Mueller (2012) found an increase of 75$90 \mathrm{~W} \mathrm{~m}^{-2}$ from terrain radiation. However, including topographic incoming longwave radiation would be associated by a decrease in the incoming sky longwave, as some of the sky view factors would be obstructed. However, as relative changes in between the base and modified model only are used as modeling outputs, these factors do not significantly impact the results.

A sensitivity analysis is used to evaluate the effect of incoming shortwave radiation, incoming longwave radiation and albedo on model results. The sensitivity analysis is a common modeling technique that allows for comparison of parameter error on model outcomes (Somers and others, 2016). The base model was run six times - twice for each of the three parameters that were varied by -10.0 and $+10.0 \%$, with the incoming shortwave radiation capped at the solar constant. The results are expressed as a percent change from the original base case simulation (Table 1). The results show that the model is most sensitive to the parameterization of the incoming shortwave radiation, with a $20.0 \%$ increase in glacial melt generation due to a $10.0 \%$ increase in shortwave radiation. The model was essentially equally sensitive to longwave radiation and albedo. Considering that incoming shortwave radiation is the main driver of melt for tropical glaciers, this result is not out of the ordinary, and reflects the sensitivity of the model to this critical parameter.

The limited length of time of the simulations, coupled with the different assumptions made for modeling $L W_{\text {margin }}$ flux
Table 1. The sensitivity of the base glacier melt model to the following parameters: incoming shortwave radiation, $S W_{i n}$ incoming longwave radiation, $L W_{i n}$ and albedo parametrization

$\%$ Change in simulated glacier melt

\begin{tabular}{llll}
$\begin{array}{l}\text { Parameter perturbation } \\
\%\end{array}$ & $\begin{array}{l}S W_{\text {in }} \\
\%\end{array}$ & $\begin{array}{l}L W_{\text {in }} \\
\%\end{array}$ & $\begin{array}{l}\text { Albedo } \\
\%\end{array}$ \\
\hline-10.0 & -17.4 & -15.0 & -14.9 \\
+10.0 & +20.1 & +15.7 & +15.7
\end{tabular}

The values are percentage change of the simulated cumulative glacier melt for the 14-day base model run for each pertubation compared with the base model run result of $10.2 \times 10^{5} \mathrm{~m}^{3}$.

related processes, requires that care should be taken in interpretation of the results. The results provide an order of magnitude of the $L W_{\text {margin }}$ effects. The simulations show how margin ablation processes can be important in tropical glaciers and indicate the potential need for more margin radiation flux oriented model developments. These developments could include longer measurements of radiation fluxes at the glacier margin, to understand better the seasonality of such flux, a better representation of the glacier margin geometry to account for local topographic variations and more sophisticated melt models.

\section{CONCLUSION}

In this study, we used ground-based thermal infrared imagery to obtain a margin longwave radiation flux, emitted from the terrain surrounding the glacier. This flux varies between 80 and $120 \mathrm{~W} \mathrm{~m}^{-2}$ diurnally and is more dependent on local shading than on elevation. We include this margin longwave flux in a physically-based melt model of the glacier to investigate the impact on local ablation and energy balance at the glacier margin. The simulations show that the margin longwave flux has a visible impact on the net radiation and the available energy for melt at the glacier margins, increasing the energy available for melt by an average of $106 \mathrm{~W} \mathrm{~m}^{-2}$ during the daytime. The addition of the longwave margin flux also results in a net radiation that averages $-6 \mathrm{~W} \mathrm{~m}^{-2}$ at night instead of $-90 \mathrm{~W} \mathrm{~m}^{-2}$. The modified model shows an additional $2722 \pm 229 \mathrm{~m}^{3}$ w.e. of melt over the 14-day study period, which is equivalent to an increase in melt of $2.7 \pm 0.2 \%$ compared with the base model, generated by $0.3 \%$ of the total glacier area.

We present a previously unquantified energy flux affecting the energy balance at the glacier margin of a Peruvian glacier. This longwave flux from the terrain adjacent to the glacier, which for the 14-day study period amounts to an additional $12.2 \mathrm{~cm}$ of ice backwasting, may potentially explain retreat patterns seen on some tropical glaciers, where accelerated mass loss is noticed not only at the lowest elevation along the glacier toe but along the entire margin of the ablation zone. As the glacier melts, the ratio of glacier margin to total area increases and the importance of the margin longwave flux derived in this study would increase. Therefore, even if this flux is not a significant input to glacier meltwater generation in this situation, it is potentially an important contribution to glacier retreat pattern.

To the best of our knowledge, this is the first quantitative assessment of the longwave energy transfer happening at 
the glacier margin of a tropical glacier. This significant energy flux should be investigated at more locations, with special attention given to the variation in margin geometry and the variation in view factors along the glacier margin. Moreover, a longer study period would be beneficial to obtain a more complete picture of the ablation pattern resulting from this longwave margin flux. More studies on this topic and the inclusion of the margin longwave energy flux into further melt modeling studies would improve the assessment of meltwater generation and ablation patterns for tropical glaciers.

With accelerated glacier loss worldwide, water resources for population downstream of glaciated terrain are threatened. This is especially true in regions with a precipitation deficit during part of the year, such as the Cordillera Blanca, Peru, where there is effectively no precipitation during the dry season (Baraer and others, 2012). This study provides valuable information to better understand the driving glacier ablation in tropical climates and predict future water availability in these already water-stressed areas.

\section{SUPPLEMENTARY MATERIAL}

The supplementary material for this article can be found at https://doi.org/10.1017/jog.2017.85

\section{ACKNOWLEDGMENT}

We thank Autoridad Nacional del Agua, in particular, the staff of the Huaraz Office, the Parque Nacional Huascarán and Jesus Gomez. We also thank Oliver Wigmore for providing the DEM of Cuchillacocha Glacier as well as James DeGrand for assisting with the instrumentation. We also thank Wolfgang Gurgiser and an anonymous reviewer whose comments greatly improved the paper. The project is supported by grants from NSERC, including the Research Tools and Instruments Program, and the National Science Foundation under grants EAR-1316429 and EAR-1316432. Additional thanks to McGill University and L'École de Technologie Supérieure de Montréal for additional support. Aubry-Wake received funding for a scholarship for Master's studies from The Fonds de recherche du Québec - Nature et technologies. Please contact the corresponding author for use of published data.

\section{REFERENCES}

Abtew W and Malesse A (2013) Evaporation and evapotranspiration. Springer, New York

Arnold NS, Willis IC, Sharp MJ, Richards KS and Lawson WJ (1996) A distributed surface energy-balance model for a small valley glacier. I. Development and testing for Haut Glacier d'Arolla, Valais, Switzerland. J. Glaciol., 42(140), 77-89

Aubry-Wake C and 6 others (2015) Measuring glacier surface temperatures with ground-based thermal infrared imaging. Geophys. Res. Lett., 42, 8489-8497 (doi: 10.1002/2015 GL065321)

Baraer $\mathrm{M}$ and 8 others (2012) Glacier recession and water resources in Peru's Cordillera Blanca. J. Glaciol., 58, 134-150 (doi: 10.3189/2012JoG11J186)

Barnett TP, Adam JC and Lettenmaier DP (2005) Potential impacts of a warming climate on water availability in snow-dominated regions. Nature, 438 (7066) (doi: 10.1038/nature04141)

Benn DI and Evans DJA (2010) Glaciers and glaciation, 2nd edn. Hodder Education, London
Brock BW, Mihalcea C, Kirkbride MP, Diolaiuti G, Cutler ME J, Smiraglia C (2010) Meteorology and surface energy fluxes in the 2005-2007 ablation seasons at the Miage debris-covered glacier, Mont Blanc Massif, Italian Alps. J. Geophys. Res., 115(D9), D09106 (doi: 10.1029/2009JD013224)

Brutsaert W (1975) On a derivable formula for long-wave radiation from clear skies. Water Resour. Res., 11, 742-744

Buri P, Pellicciotti F, Steiner J, Miles E and Immerzeel W (2016) A grid-based model of backwasting of supraglacial ice cliffs on debris-covered glaciers. Ann. Glaciol., 57(71), 199-210 (doi: 10.3189/2016aog71a059)

Chinn T (1987) Accelerated ablation at a Glacier Ice-Cliff Margin, Dry Valleys. Arct. Antarct. Alp. Res., 19(1), 71-80

Cuffey KM and Paterson SB (2010) The physics of glaciers. Butterworth-Heinemann/Elsevier, Burlington, MA

Delclaux F, Coudrain A and Condom T (2007) Evaporation estimation on Lake Titicaca: a synthesis review and modelling. Hydrol. Process., 21, 1664-1677 (doi: 10.1002/hyp.6360)

Favier V, Wagnon P and Ribstein P (2004a) Glaciers of the outer and inner tropics: a different behaviour but a common response to climatic forcing. Geophys. Res. Lett., 31, L16403 (doi: 10.1029/ 2004GL020654)

Favier V, Wagnon P, Chazarin JP, Maisincho L and Coudrain A (2004b) One-year measurements of surface heat budget on the ablation zone of Antizana Glacier 15, Ecuadorian Andes. J. Geophys. Res. Atmos., 109 (18) (doi: 10.1029/2003JD004359)

Fierz C, Pluss C and Martin E (1997) Modelling the snow cover in a complex alpine topography. Ann. Glaciol., 25, 312-316

Francou B, Vuille M, Favier V and Cáceres B (2004) New evidence for an ENSO impact on low latitude glaciers: Antizana 15, Andes of Ecuador, 0²8'S. J. Geophys. Res., 109, D18106 (doi: 10.1029/2003JD004484)

Gardelle J, Berthier E, Arnaud Y and Kääb A (2013) Region-wide glacier mass balances over the Pamir-Karakoram-Himalaya during 1999-2011. Cryosphere, 7(4), 1263-1286 (doi: 10. 5194/tc-7-1263-2013)

Garnier B and Ohmura A (1968) A method of calculating the direct shortwave radiation income on slopes. J. Appl. Meteor., 7, 796-800

Gratton DJ, Howarth PJ and Marceau DJ (1993) Using Landsat-5 thematic mapper and digital elevation data to determine the net radiation field of a mountain glacier. Remote Sen., Environ., 43 (3), 315-331

Gurgiser W, Mölg T, Nicholson L and Kaser G (2013a) Mass balance model parameter transferability on a tropical glacier. J. Glaciol., 59, 845-858 (doi: 10.3189/2013JoG12J226)

Gurgiser W, Marzeion B, Nicholson L, Ortner M and Kaser G (2013b). Modeling energy and mass balance of Shallap Glacier, Peru. Cryosphere, 7, 1787-1802 (doi: 10.5194/tc-71787-2013)

Han H, Wang J, Wei J and Liu S (2010) Backwasting rate on debris covered Koxkar glacier, Tuomuer mountain, China. J. Glaciol., 56, 287-296 (doi: 10.3189/002214310791968430)

Hannah DM, Gurnell AM and McGregor GR (2000) Spatio-temporal variation in microclimate, the surface energy balance and ablation over a cirque glacier. Int. J. Climatol. 20, 733-758

Hock R (2005) Glacier melt: a review of processes and their modelling. Prog. Phys. Geogr., 29, 362-391 (doi: 10.1191/ 0309133305pp453ra)

Hock R and Noetzli C (1997) Areal melt and discharge modelling of Storglaciären, Sweden. Ann. Glaciol., 24, 211-217

Jiskoot $\mathrm{H}$ and Mueller MS (2012) Glacier fragmentation effects on surface energy balance and runoff: field measurements and distributed modelling. Hydrol. Process., 26(12), 1861-1875

Johnson GT and Watson ID (1984) The determination of viewfactors in urban canyons. J. Appl. Meteorol. Climatol., 23 (2), 329-335

Kaser G and Osmaston H (2002) Tropical glaciers. Cambridge University Press, Cambridge 
Kustas WP, Rango A and Uijlenhoet R (1994) A simple energy budget algorithm for the snowmelt runoff model. Water Resour. Res., 30(5), 1515-1527 (doi: 10.1029/94WR00152)

Lewis KJ, Fountain A and Dana GL (1998) Surface energy balance and meltwater production for a Dry Valley glacier, Taylor Valley, Antarctica. Ann. Glaciol., 27, 603-609

Machguth H, Purves RS, Oerlemans J, Hoelzle M and Paul F (2008) Exploring uncertainty in glacier mass balance modelling with Monte Carlo simulation. Cryosphere, 2, 191-204

Marks D and Dozier J (1979) A clear-sky longwave radiation model for remote alpine areas. J. Arch. Met. Geoph. Biokl. B., 27, 159-178

Mölg T and Hardy DR (2004) Ablation and associated energy balance of a horizontal glacier surface on Kilimanjaro. J. Geophys. Res., 109, D16104 (doi: 10.1029/2003JD004338)

Mölg T, Cullen NJ, Hardy DR, Kaser G and Klok L (2008) Mass balance of a slope glacier on Kilimanjaro and its sensitivity to climate. Int. J. Climatol., 28, 881-892 (doi: 10.1002/joc.1589)

Nicholson LI and 5 others (2010) Glacier inventory of the upper Huasco valley, Norte Chico, Chile: glacier characteristics, glacier change and comparison to central Chile. Ann. Glaciol., 50(53), 111-118 (doi: 10.3189/172756410790595787)

Nicholson LI, Prinz R, Mölg T and Kaser G (2013) Micrometeorological conditions and surface mass and energy fluxes on Lewis Glacier, Mt Kenya, in relation to other tropical glaciers. Cryosphere, 7, 1205-1225 (doi: 10.5194/tc-7-12052013)

Ohta T (1994) A distributed snowmelt prediction model in mountain areas based on an energy balance method. Ann. Glaciol., 19, 107-113

Olyphant G (1986) Longwave radiation in mountainous areas and its influence on the energy balance of alpine snowfields. Water Resourc. Res., 22, 62-66

Pellicciotti F, Ragettli S, Carenzo M and McPhee J (2014) Changes of glaciers in the Andes of Chile and priorities for future work. Sci. Total Environ., 493, 1197-1210 (doi: 10.1016/j.scitotenv. 2013.10.055)

Pellicciotti F, Stephan C, Miles E, Immerzeel WW and Bolch T (2015) Mass balance changes of debris-covered glaciers in the Langtang Himal in Nepal between 1974 and 1999. J. Glaciol., 61, 373-386 (doi: 10.3189/2015JoG13J237)

Plüss C and Ohmura A (1997) Longwave radiation on snow-covered mountainous surfaces. J. Appl. Meteor., 36, 818-824

Reid T and Brock B (2014) Assessing ice-cliff backwasting and its contribution to total ablation of debris-covered Miage glacier, Mont Blanc massif, Italy. J. Glaciol., 60(219), 3-13 (doi: 10.3189/2014JoG13J045)
Rigaudiere P, Ribstein P, Francou B, Pouyaud B and Saravia R (1995) Un modèle hydrologique du glacier Zongo. Coll. «INFORME». La Paz, Bolivia: L'institut Francais de Recherche Scientifique pour le Développement en Coopération

Sakai A, Nakawo M and Fujita K (1998) Melt rate of ice cliffs on the Lirung Glacier, Nepal Himalayas, 1996. Bull. Glacier Res., 16, $57-66$

Sakai A, Nakawo M and Fujita K (2002) Distribution characteristics and energy balance of ice cliffs on debris-covered glaciers, Nepal Himalaya. Arct. Antarct. Alp. Res., 34(1), 12-19 (doi: 10.2307/ 1552503)

Sicart JE, Pomeroy JW, Essery RHL and Bewley D (2006) Incoming longwave radiation to melting snow: observations, sensitivity and estimation in Northern environments. Hydrol. Process., 20, 3697-3708 (doi: 10.1002/hyp.6383)

Sicart JE, Hock R, Ribstein P, Litt M and Ramirez E (2011) Analysis of seasonal variations in mass balance and meltwater discharge of the tropical Zongo Glacier by application of a distributed energy balance model. J. Geophys. Res., 116, D13105 (doi: 10.1029/2010JD015105)

Somers LD and 10 others (2016) Quantifying groundwater-surface water interactions in a proglacial valley, Cordillera Blanca, Peru. Hydrol. Process., 30, 2915-2929 (doi: 10.1002/hyp. 10912)

Steiner J and 5 others (2015) Modelling ice cliff backwasting on a debris covered glacier in the Nepalese Himalayas. J. Glaciol., 61(229), 889-907 (doi: 10.3189/2015JoG14J194)

Wagnon P, Ribstein P, Francou B and Pouyaud B (1999a) Annual cycle of energy balance of Zongo Glacier, Cordillera Real, Bolivia. J. Geophys. Res., 104(D4), 3907-3923 (doi: 10.1029/ 1998JD200011)

Wagnon P, Ribstein P, Kaser G and Berton P (1999b) Energy balance and runoff seasonality of a Bolivian glacier. Glob. Planet.Change, 22 (1-4), 49-58 (doi: 10.1016/S0921-8181(99)00025-9)

Wigmore O and Mark B (2017) Monitoring tropical debris-covered glacier dynamics from high-resolution unmanned aerial vehicle photogrammetry, Cordillera Blanca, Peru. Cryosphere, 11, 2463-2480 (doi: 10.5194/tc-11-2463-2017)

Winkler M and 5 others (2009) Measured and modelled sublimation on the tropical Glaciar Artesonraju, Perú. Cryosphere, 3, 21-30 (doi: 10.5194/tc-3-21-2009)

Winkler $M$ and 5 others (2010) Land-based marginal ice cliffs: focus on Kilimanjaro. Erdkunde, 64(2), 179-193 (doi: 10.3112/ erdkunde.2010.02.05) 